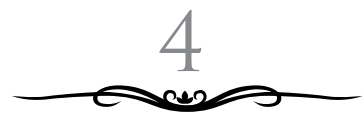

\title{
PENGGUNAAN MEDIA SOSIAL OLEH PERPUSTAKAAN
}

\author{
Purwani \\ UGM Yogyakarta, DIY, Indonesia \\ Nina@ugm.ac.id
}

\begin{abstract}
Information and communication technology has affected people's daily behavior, including library users. Users of the library using information technology for various purposes, entertainment, access information, and to socialize. Socialization through online media has become one of the needs of the user community. Library users want to connect to friends, relatives, and others through social media. Libraries are aware of this, so as to connect with users, libraries are also using social media, one of which is Facebook. This study aims to determine the frequency of use of Facebook by the library and how the use of Facebook by the library. Researcher examines three faculty libraries in Gadjah Mada University Yogyakarta, namely Facebook Library Faculty of Geography, Faculty of Social and Political Sciences Library, and the Library of the Faculty of Agriculture. The data collection techniques use documentation on the library's Facebook page under investigation. The data collected documentation on the Facebook page of the library was analyzed using quantitative descriptive analysis. The study results show that ISIPOL Library is a library that has the most frequent use of Facebook ie daily. The library is using social media Facebook to promote the library collections, promote events or library services, upload photos/ images of activities that have been carried out of the library, develop services circulation, inform the internal activities of the library, to promote the activities of other libraries, informing
\end{abstract}


various things important for users, and greets users. Each library in use of Facebook shows the activity and intensity are different.

Keyword: Library Services, Social Media, Library.

\begin{abstract}
Abstrak
Teknologi informasi dan komunikasi telah mempengaruhi perilaku keseharian masyarakat, termasuk pengguna perpustakaan. Pengguna perpustakaan menggunakan teknologi informasi untuk berbagai tujuan, hiburan, akses informasi, dan bersosialisasi. Sosialisasi melalui media online telah menjadi salah satu kebutuhan pengguna masyarakat. Pengguna perpustakaan ingin selalu terkoneksi dengan teman, saudara, dan lain-lain melalui media sosial. Perpustakaan menyadari hal ini, sehingga untuk terkoneksi dengan penggunanya, perpustakaan juga menggunakan media sosial, salah satunya adalah Facebook. Kajian ini bertujuan untuk mengetahui frekuensi penggunaan Facebook oleh perpustakaan dan bagaimana penggunaan Facebook oleh perpustakaan. Peneliti mengkaji tiga perpustakaan fakultas di lingkungan Universitas Gadjah Mada Yogyakarta, yakni Perpustakaan Fakultas Geografi, Perpustakaan Fakultas ISIPOL, dan Perpustakaan Fakultas Pertanian. Teknik pengumpulan data menggunakan dokumentasi pada laman Facebook perpustakaan yang diteliti. Hasil pengumpulan data dokumentasi pada laman Facebook perpustakaan dianalisis menggunakan analisis deskriptif kuantitatif. Hasil kajian menunjukkan bahwa Perpustakaan ISIPOL merupakan perpustakaan yang memiliki frekuensi penggunaan Facebook paling sering, yakni setiap hari. Perpustakaan menggunakan Facebook untuk mempromosikan koleksi perpustakaan, mempromosikan kegiatan atau layanan perpustakaan, mengunggah foto/gambar kegiatan yang telah dilakukan perpustakaan, mengembangkan jasa layanan sirkulasi, menginformasikan kegiatan internal perpustakaan, mempromosikan kegiatan dari perpustakaan lain, menginformasikan berbagai hal yang penting bagi pengguna, dan menyapa penggunanya. Setiap perpustakaan dalam
\end{abstract}


penggunaan Facebook menunjukkan aktivitas dan intensitas yang berbeda-beda.

Kata Kunci: Layanan Perpustakaan, Media Sosial, Perpustakaan.

\section{A. Pendahuluan}

Teknologi informasi merupakan bagian dari kehidupan keseharian masyarakat. Perangkat teknologi seperti handphone, smartphone, laptop, dan jenis gadget yang lain menjadi satu hal yang melekat dalam keseharian sebagian masyarakat kita. Sebagian besar masyarakat menggunakan perangkat teknologi hampir dua pertiga waktu yang dimilikinya karena perangkat teknologi adalah bagian dari alat yang digunakannya dalam bekerja. Jika tidak untuk bekerja, masyarakat menggunakan perangkat teknologi untuk melakukan komunikasi atau pun untuk mengakses informasi. Oleh karena itu, konektivitas merupakan hal penting bagi masyarakat saat ini.

Perangkat teknologi yang saat ini cukup banyak dimanfaatkan adalah smartphone. Dikatanya oleh Kurniawan ${ }^{1}$ bahwa penggunaan teknologi informasi terutama smartphone pada masyarakat kita mulai marak sejak tahun 2000 hingga tahun 2014. Penggunaan smartphone menawarkan berbagai aktivitas maksimal yang dapat dilakukan. Smartphone mampu memberikan pilihan aktivitas, antara lain membaca dokumen, membuat agenda kegiatan dengan alat pengingat (alarm), mendengarkan musik, merekam suara dan gambar, memotret, melihat video, mendengar radio, melihat televisi, dan sebagainya. Pilihan-pilihan tersebut membuat sebagian penggunanya seolah tidak mungkin jauh dari smartphone mereka.

Perangkat teknologi informasi memungkinkan penggunanya terkoneksi. Generasi saat ini ingin selalu terkoneksi

${ }^{1}$ Cynthia Amanda Utami Kurniawan, "Hubungan antara Perkembangan Keterampilan Komunikasi Interpersonal pada Remaja Awal dengan Kecanduan Smartphone", Skripsi, Universitas Gadjah Mada Yogyakarta, 2016. 
sehingga mereka dapat melakukan berbagai aktivitas dengan menggunakan perangkat teknologi yang dibawanya. Hal ini dapat kita buktikan di tempat-tempat yang menyediakan akses WiFi gratis selalu diminati oleh generasi muda. Yang penulis maksud dengan generasi muda di dalam tulisan ini adalah generasi usia Sekolah Menengah Atas dan usia kuliah atau mahasiswa. Tempat atau lokasi yang menyediakan akase WiFi antara lain tempattempat hiburan, rumah makan (seperti McDonal, KFC), mall, cafe, resto, perpustakaan, dan sebagainya.

Melihat kenyataan di atas, terlihat bahwa beberapa lokasi komersilsial seperti rumah makan dan cafe telah menyadari pentingnya akses internet bagi pengunjungnya. Mereka menyadari bahwa akses WiFi merupakan salah satu daya tarik orang untuk datang berkunjung dan betah berada di sana. Itu artinya makanan yang mereka jual akan laku. Apabila pengunjung betah berada di sana, itu juga berarti bahwa makanan dan atau minuman yang mereka tawarkan semakin banyak yang terjual.

Perpustakaan juga telah menyadari hal ini. Perpustakaan menyediakan akses WiFi di perpustakaan, untuk memberikan keleluasaan bagi pengguna untuk mengakses sumber informasi dan pengetahuan digital. Perpustakaan menyajikan sebagian referensi dalam format digital, seperti jurnal online, e-book, proseding, katalog perpustakaan dan sebagainya. Untuk akses sumber informasi digital perpustakaan, diperlukan jaringan internet, sehingga sangat tepat jika ada layanan atau fasilitas akses internet untuk pengguna. Pemanfaatan WiFi perpustakaan selain untuk mengakses sumber-sumber pengetahuan, juga digunakan untuk bersosialisasi dan berkomunikasi melalui media sosial.

Media sosial telah menjadi kebutuhan bagi individu ataupun institusi untuk mengembangkan produk dan menjaga kesetiaan pelanggannya. Seseorang ingin selalu terkoneksi dengan jaringan internet, terkait keinginannya untuk selalu terhubung dengan pekerjaannya, tugas, teman, dan informasi yang terus tumbuh dan berkembang. Koneksitas dengan teman dilakukan melalui media 
sosial. Media sosial sebagai media untuk saling bertukar informasi dan berinteraksi.

Melalui media sosial, institusi dapat berkomunikasi dengan pelanggan atau user dengan lebih mudah dan cepat. Informasi dapat disampaikan dengan cara yang mudah dan tepat sasaran. Perpustakaan merupakan salah satu institusi yang mulai memanfaatkan media sosial untuk berkomunikasi dengan penggunanya. Pada awalnya komunikasi hanya dilakukan melalui e-mail, namun saat ini semakin berkembang dengan memanfaatkan media sosial, seperti Facebook, Twitter, Whatshap, dan sebagainya. Komunikasi melalui media sosial antara perpustakaan dan pengguna dipandang efektif.

Namun, efektivitas pemanfaatan media sosial ini belum banyak dimanfaatkan oleh perpustakaan. Perpustakaan menyadari bahwa sebagian besar penggunanya aktif di media sosial Facebook, sehingga merasa perlu juga perpustakaan menggunakannya. Interaksi melalui media sosial antara pustakawan dan pengunanya dapat mencairkan suasana dan membangun image baru tentang pustakawan. Namun, hal ini tidak diiringi dengan konsisten dalam pemanfaatannya. Masih cukup banyak perpustakaan yang mempunyai akun Facebook namun tidak secara rutin meng-update informasi tentang perpustakaan di media sosial yang dimiliki. Bahkan, pesan yang masuk melalui media sosial terkadang terlambat direspons. Hal ini tentu saja membangun ketidakpercayaan pengguna terhadap akun media sosial perpustakaan.

Permasalahan di atas menggugah penulis untuk menyajikan paparan tentang penggunaan media sosial (Facebook) oleh perpustakaan. Penelitian ini fokus pada masalah:

1. Seberapa sering perpustakaan menggunakan Facebook?

2. Bagaimana penggunaan media sosial Facebook oleh perpustakaan?

Pemaparan makalah ini didasarkan pada studi pustaka dan data dokumentasi pada laman Facebook tiga perpustakaan di lingkungan Universitas Gadjah Mada, yaitu Facebook Perpustakaan Fakultas Ilmu Sosial Politik, Facebook Perpustakaan 
Fakultas Geografi, dan Facebook Perpustakaan Fakultas Pertanian Universitas Gadjah Mada. Data dokumentasi pada Facebook perpustakaan dibatasi pada tahun 2016. Analisis yang digunakan dalam kajian sederhana ini adalah analisis deskriptif kuantitatif terhadap posting (kiriman) konten pada masing-masing Facebook perpustakaan.

\section{B. Pembahasan}

\section{Media Sosial}

Media sosial disingkat medsos telah menjadi bagian dalam perilaku keseharian sebagian masyarakat. Apa yang dimaksud dengan media sosial itu? Di antara pembaca pastilah memiliki akun media sosial. Melalui media sosial kita dapat berinteraksi dengan orang lain, memperoleh informasi, memberikan feedback atas informasi yang kita baca pada akun kita, men-share informasi atau dokumen, men-download informasi yang menurut kita perlu untuk kita simpan, dan sebagainya. Menurut Njoroge, ${ }^{2}$ dikatakan bahwa media sosial merupakan istilah yang tidak memiliki definisi makna yang pasti. Namun, media sosial mudah dipahami dengan memisahkan antara sosial dan media. Media adalah instrumen komunikasi seperti surat kabar atau radio, sehingga media sosial adalah instrumen sosial komunikasi. Tentu saja ada perbedaan antara media seperti surat kabar, radio, dan televisi (saya sebut sebagai media reguler) dengan media sosial. Media reguler lebih sebagai satu arah dalam berkomunikasi. Ketika kita mendengar radio, membaca surat kabar, atau melihat tayangan televisi, maka kita hanya sebagai penerima pesan, tidak dapat melakukan feedback secara langsung. Namun pada media sosial, sebagai contoh Facebook, pengguna dapat memberikan feedback langsung atas pesan yang dibaca. Feedback sederhana misalnya memberikan apresiasi "like" atau "dislike", menyampaikan komentar, atau bahkan menambahkan informasi yang kita miliki. Media sosial

${ }^{2}$ G.G. Njoroge dan P. Kang, "University Libraries and Social Media”, 1, September 2011, hlm. 37-42. 
memberikan pilihan format komunikasi yang interaktif dan memungkinkan pengguna untuk berbagi informasi.

Berbagai media sosial yang saat ini digunakan di banyak perpustakaan menurut King ${ }^{3}$ adalah Facebook, Twitter, YouTube, Linkedln, Tumblr, Pinterest, Instagram, Snapchat, Vine, Google Plus, dan Flickr. Perpustakaan di Indonesia cukup banyak memanfaatkan Facebook sebagai media komunikasi dua arah dengan user. Facebook resmi diluncurkan oleh Mark Zuckerberg pada Februari 2004. Umumnya perpustakaan memanfaatkan Facebook untuk menginformasikan berita-berita perpustakaan, terkait koleksi yang baru mereka miliki, kegiatan yang akan mereka selenggarakan, mengundang pengguna untuk datang mengikuti kegiatan perpustakaan, kegiatan yang baru saja atau sedang berlangsung di perpustakaan, menginformasikan keterlambatan pengembalian buku, dan sebagainya. Media sosial Twitter juga digunakan oleh perpustakaan. King3 mengatakan bahwa jumlah pengguna Twitter tidak sebanyak pengguna Facebook. Namun demikian, beberapa perpustakaan memanfaatkan media sosial Twitter untuk berbagi informasi baru dan terkini tentang perpustakaan dan hal-hal yang terkait dengan kebutuhan pengguna perpustakaan.

\section{Penggunaan Facebook Oleh Perpustakaan}

Dikatakan oleh Canty, ${ }^{4}$ sosial media dapat menjadi perangkat dialog dua arah untuk penyebaran informasi dan menawarkan cara bagi perpustakaan untuk mempromosikan aktivitas, sumber informasi dan layanannya kepada stakeholder. Hasil penelitian Chu (2013) terhadap 38 perpustakaan universitas di Asia, Amerika Utara, dan Eropa menemukan bahwa 71,1\% menggunakan jaringan sosial. Mereka umumnya mengadopsi Facebook dan Twitter. Sebesar 13,1\% berpotensi untuk menggunakan serta $15,8 \%$ sama sekali tidak berencana untuk menggunakan jaringan sosial.

${ }^{3}$ David L. King, "Landscape of Social Media for Libraries", Library Technology Reports, 51 (1), 2015, hlm. 10-15, https://search.proquest.com/docv iew/1646465094? accountid=13771.

${ }^{4}$ Nick Canty, “Social Media in Libraries: It's Like Complicated”, 2012. 
Berikut ini gambaran frekuensi penggunaan Facebook oleh tiga perpustakaan yang digunakan sebagai objek kajian sederhana ini. Seberapa sering perpustakaan menggunakan Facebook? Berdasarkan data yang penulis peroleh melalui tiga akun Facebook perpustakaan di lingkungan Universitas Gadjah Mada, yaitu Perpustakaan Fakultas Geografi, Perpustakaan Fakultas Pertanian, dan Perpustakaan ISIPOL selama tahun 2016, diperoleh data sebagai berikut.

Tabel 1. Jumlah Posting pada Facebook Perpustakaan

\begin{tabular}{lr}
\hline \multicolumn{1}{c}{ Nama Perpustakaan } & Posting \\
\hline Perpustakaan Fakultas Geografi & 20 \\
\hline Perpustakaan Fakultas Pertanian & 53 \\
\hline Perpustakaan ISIPOL & 336 \\
\hline
\end{tabular}

Sumber: Data dokumentasi laman Facebook, 2016.

Perpustakaan Fakultas ISIPOL terbanyak melakukan posting di antara dua perpustakaan lainnya, diikuti Perpustakaan Fakultas Pertanian dan yang terakhir Perpustakaan Fakultas Geografi. Data pada Tabel 1 menjawab pertanyaan pertama pada kajian ini. Terlihat bahwa dalam satu tahun (366 hari) rata-rata Perpustakaan Fakultas Geografi mem-posting atau menggunakan Facebook setiap 18 hari sekali. Perpustakaan Fakultas Pertanian menggunakan Facebook setiap 7 hari sekali dan Perpustakaan ISIPOL rata-rata penggunaan Facebook setiap satu hari sekali (setiap hari). Hal ini menunjukkan bahwa penggunaan Facebook oleh perpustakaan masih belum optimal, jika ingin menjangkau penggunanya yang dominan menggunakan media sosial, di antaranya facebook.

Penggunaan media sosial (Facebook) digunakan oleh perpustakaan untuk berbagai keperluan. Berdasarkan data dari ketiga perpustakaan tersebut diperoleh data bahwa pengguna media sosial antara lain sebagai berikut.

Pertama, penggunaanmedia sosialuntukmenginformasikan koleksi baru perpustakaan. Selain mempromosikan koleksi 
tercetaknya, mereka juga mempromosikan koleksi e-book dan e-journal. Ketika perpustakaan memiliki koleksi baru, maka melalui media sosial, koleksi baru tersebut diinformasikan kepada penggunanya. Penggunaan media sosial Facebook untuk mempromosikan koleksi baru ini dilakukan oleh Perpustakaan Fakultas Geografi dan Perpustakaan Fakultas Pertanian. Burkhardt ${ }^{5}$ dalam artikel berjudul "Sosial Media: a Guide for College and University Libraries" memberikan ide tentang penggunaan media sosial untuk memberitahu pengguna akan adanya koleksi baru perpustakaan. Penggunaan media sosial cukup efektif untuk menginformasikan kepada pembaca semuanya tentang adanya koleksi baru di perpustakaan. Apa yang diinformasikan kepada pengguna merupakan suatu hal yang ditunggu oleh penggunanya. Hal ini berdasarkan hasil penelitian Larasati $^{6}$ dalam kajiannya terhadap 75 pengguna Facebook perpustakaan bahwa mereka membuka Facebook perpustakaan untuk mendapatkan informasi baru dan mengetahui program yang dilaksanakan perpustakaan.

Kedua, penggunaan media sosial untuk mempromosikan layanan/kegiatan perpustakaan yang dapat diikuti oleh pengguna. Promosi layanan perpustakaan lebih efektif dengan memanfaatkan media sosial. Hal ini juga dinyatakan oleh Burkhardt, ${ }^{7}$ yang memberikan beberapa ide hal-hal yang bisa diposting oleh perpustakaan melalui media sosial, di antaranya berita baru atau even baru perpustakaan. Contohnya antara lain menayangkan jenis layanan yang ada di perpustakaan, bermanfaat untuk mengingatkan kembali bahwa perpustakaan bersedia membantu pengguna melalui layanan yang disediakan. Mengundang mahasiswa untuk datang di acara yang diselenggarakan perpustakaan.

${ }^{5}$ Andy Burkhardt, "Sosial Media: a Guide for College and University Libraries", College and Research Libraries News, Vol. 71, No. 1, Januari 2010, hlm. 10-24.

${ }^{6}$ Anitya Putri Larasati, "Pemanfaatan Facebook Perpustakaan: Studi Deskriptif Pemanfaatan Jejaring Sosial (Facebook) di Kalangan Anggota Facebook Perpustakaan Kabupaten Sidoarjo", Libri-Net, Vol. 2, No. 2, 2013, http://journal.unair.ac.id/table_of_content_136_volume2_nomor2.html.

${ }^{7}$ Ibid. 
Mempromosikan layanan/jasa baru juga dapat dilakukan dengan media sosial dan atau perubahan aturan atas layanan yang telah diberikan. Misalnya perubahan jumlah buku yang bisa dipinjam, informasi kegiatan pelatihan, workshop, seminar di perpustakaan yang bisa diikuti pengguna, kegiatan pameran perpustakaan, dan lain sebagainya. Hal ini dilakukan oleh ketiga perpustakaan. Perpustakaan Fakultas Geografi menggunakan Facebook untuk mengajak dan mengundang mahasiswa untuk mengikuti kegiatan sosialisasi database e-journal dan sosialisasi kegiatan pelatihan Mendeley pada posting tanggal 9 September 2016. Pada tanggal 10 Mei 2016, Perpustakaan Fakultas ISIPOL menggunakan Facebook untuk mengajak mahasiswa mengikuti kegiatan perpustakaan berupa sosialisasi Unggah Mandiri. Pada tanggal 6 September 2016, Perpustakaan Fakultas Pertanian mengajak pemustaka mengikuti kegiatan workshop database yang diselenggarakan perpustakaan. Canty ${ }^{8}$ juga menekankan bahwa media sosial sebagai cara dua arah untuk promosi kegiatan yang dilakukan perpustakaan.

Ketiga, penggunaan media sosial untuk mengunggah/ menginformasikan kegiatan yang telah dilakukan perpustakaan. Setelah perpustakaan melaksanakan suatu kegiatan, pustakawan akan mengunggah foto kegiatan beserta informasi singkat tentang kegiatan yang baru saja dilaksanakan perpustakaan. Hal ini juga sebagai bahan laporan kepada pengguna bahwa perpustakaan telah berhasil menyelesaikan satu kegiatan. Misalnya perpustakaan baru saja menyelesaikan kegiatan literasi informasi, maka perpustakaan akan mengunggah foto-foto kegiatan tersebut. Perpustakaan Fakultas Geografi melakukan unggah foto atau gambar kegiatan setelah melaksanakan kegiatan literasi informasi bagi mahasiswa S3 dan mahasiswa Diploma pada 18 Agustus 2016. Hal ini dilakukan pula oleh Perpustakaan Fakultas Pertanian pada tanggal 22 Maret 2016 yang mengunggah foto/gambar aktivitas perpustakaan. Namun, hal ini tidak dilakukan oleh Perpustakaan Fakultas ISIPOL sepanjang tahun 2016.

\footnotetext{
${ }^{8}$ Ibid.
} 
Keempat, mengembangkan jasa layanan sirkulasi. Pengembangan layanan sirkulasi dengan memanfaatkan layanan perpanjangan buku melalui Facebook. Penggunaan Facebook untuk mengembangkan jasa layanan perpanjangan buku dominan dilakukan oleh Perpustakaan Fakultas ISIPOL. Dikatakan dominan karena dari 336 posting yang dilakukan perpustakaan, sebagian besar digunakan untuk menjawab permintaan perpanjangan mahasiswa dalam memperpanjang waktu pinjam bukunya, menagih peminjaman yang terlambat, serta informasi denda keterlambatan pengembalian. Hanya 10 posting dilakukan perpustakaan di luar seputar layanan sirkulasi, sehinggga dapat dikatakan bahwa Perpustakaan Faakultas ISIPOL UGM menggunakan Facebook untuk mengembangkan jasa layanan sirkulasi. Pada laman Facebook terlihat respons yang dilakukan perpustakaan ada yang segera dan ada yang tidak. Misalnya, permohonan perpanjangan pada pukul 10.53 WIB, respons dari perpustakaan pukul 13.07 WIB. Ada pula permintaan perpanjangan pada hari ini, direspons pada esok harinya. Terlihat bahwa pengguna (mahasiswa) aktif menjalin komunikasi dengan perpustakaan untuk melakukan perpanjangan peminjaman buku. Perpustakaan juga menyapa pengguna yang terlambat mengembalikan buku dan buku dimohon untuk segera mengingatkan pengguna atas buku yang harus segera dikembalikan, dilakukan melalui Facebook.

Kelima, penggunaan media sosial untuk menyampaikan informasi kegiatan internal perpustakaan. Kegiatan internal yang dimaksud adalah kegiatan yang tidak berhubungan langsung dengan pengguna. Kegiatan ini antara lain kegiatan ulang tahun perpustakaan, kegiatan staf, renovasi ruang perpustakaan, dan sebagainya. Hal ini dilakukan pada Facebook Perpustakaan Fakultas Geografi, ketika selesai melakukan pembenahan ruang perpustakaan pada 18 Agustus 2016. Pada Facebook Perpustakaan Fakultas Pertanian juga menampilkan foto kegiatan internal staf perpustakaan pada 1 Maret 2016.

Keenam, penggunaan Facebook untuk mempromosikan kegiatan dari perpustakaan lain. Misalnya Perpustakaan Fakultas 
Teknik akan melakukan kegiatan pelatihan bagi mahasiswa, maka perpustakaan ikut mempromosikan dengan memanfaatkan Facebook perpustakaan. Ini dilakukan oleh Perpustakaan Fakultas Pertanian mempromosikan kegiatan Perpustakaan Fakultas lain pada 16 Agustus 2016 dan juga oleh Perpustakaan Fakultas Geografi pada 26 Agustus 2016. Hal ini tidak dilakukan oleh Perpustakaan Fakultas ISIPOL sepanjang tahun 2016.

Ketujuh, penggunaan media sosial untuk menginformasi hal-hal yang penting bagi penggunanya. Contoh hal-hal penting bagi pengguna antara lain menginformasikan tentang adanya beasiswa (informasi magang bagi mahasiswa), informasi terkait aturan pemerintah yang berhubungan dengan pengguna perpustakaan dan sebagainya serta informasi lain yang dianggap penting diketahui mahasiswa. Hal ini dilakukan oleh Perpustakaan Fakultas Pertanian pada 23 Mei 2016 yang menginformasikan tentang Simlitabmas dari Dirjen Dikti.

Kedelapan, penggunaan media sosial untuk menyapa pengguna mengucapkan salam. Beberapa media sosial digunakan untuk menyapa pengguna dengan ucapan selamat, seperti: "Selamat Tahun Baru", "Selamat Hari Natal", "Selamat telah menyelesaikan studi”, dan sapaan lainnya. Hal ini dilakukan oleh Perpustakaan Fakultas Geografi melalui Facebook perpustakaan pada 4 Agustus 2016 dan juga oleh Perpustakaan Fakultas Pertanian pada 28 September 2016. Itmamudin ${ }^{9}$ menyatakan bahwa situs jejaring sosial dapat digunakan untuk bersosialisasi. Menyapa pengguna melalui jejaring sosial telah pula dilakukan oleh perpustakaan di lingkungan Universitas Gadjah Mada. Berdasarkan ketiga Facebook perpustakaan tersebut, yang memiliki posting (kiriman) yang cukup bervariasi adalah Facebook Perpustakaan Fakultas Pertanian, diikuti Perpustakaan Geografi, dan yang terakhir Perpustakaan Fakultas ISIPOL. Perpustakaan Fakultas ISIPOL

${ }^{9}$ Itmamudin, “Implementasi Library 3.0 di Perpustakaan IAIN Salatiga: Masalah dan Solusinya”, Libraria: Jurnal Perpustakaan, Vol. 4, No. 1, Juni 2016, hlm. 207-222. 
penggunaan Facebook dominan untuk pelayanan perpanjangan peminjaman buku.

\section{Efektivitas Penggunaan Facebook Oleh Perpustakaan}

a. Lebih efektif dan efisien untuk berbagi informasi

Seperti dikatakan oleh Canty ${ }^{10}$ bahwa melalui media sosial, perpustakaan dapat menjalin komunikasi dua arah dengan pengguna, sehingga dalam kajian akan dipaparkan respon pengguna terhadap posting perpustakaan. Berdasarkan hasil observasi pada laman tiga Facebook perpustakaan tersebut dapat diketahui bahwa pengguna cukup responsif terhadap posting yang dilakukan perpustakaan. Hal ini terlihat bahwa pengguna cukup antusias memanfaatkan, menanggapi, informasi, gambar, dan video yang diunggah perpustakaan melalui Facebook. Pada 21 November 2016 pukul 15.52 WIB, Facebook Perpustakaan Fakultas Geografi mem-posting koleksi baru perpustakaan, pada pukul 16.21 WIB dan 16.23 WIB sudah ada pengguna yang mengomentari apa yang disampaikan perpustakaan. Gambar 1 menunjukkan contoh komunikasi perpustakaan dengan pengguna melalui Facebook. Contoh lain pada Facebook Perpustakaan Fakultas Pertanian pada tanggal 25 Oktober 2016 pukul 15.40 WIB mengunggah informasi tentang koleksi Perpustakaan Nasional yang dapat diakses, pada pukul 15.56 WIB telah mendapat respons dari penggunanya. Sekali lagi penulis sampaikan bahwa pengguna cukup responsif terhadap informasi yang disampaikan perpustakaan melalui Facebook. Hal ini berarti pula bahwa perpustakaan dapat menemui penggunanya melalui jalur ini secara lebih efektif. Perpustakaan dapat menyampaikan berbagai informasi lebih efisien dan efektif serta respons yang lebih cepat dari pengguna.

b. Selalu terhubung dengan penggunanya

Media sosial memungkinan perpustakaan dapat berinteraksi langsung dua arah dengan pengguna menjadi satu pilihan yang lebih menguntungkan daripada menggunakan media regular. Perpustakaan tetap mampu berkomunikasi dengan penggunanya

${ }^{10}$ Ibid. 
dengan perangkat yang lebih murah. Telah disebutkan sebelumnya bahwa perpustakaan dan pustakawan menggunakan Facebook untuk menyapa pengguna. Hal ini tentu saja sebagai upaya perpustakaan untuk terus terhubung dengan pengguna dengan jalinan komunikasi dua arah yang lebih baik.

c. Menjangkau pengguna yang lebih luas

Perpustakaan dapat menginformasi dan melakukan promosi layanannya dengan jangkauan yang lebih luas. Dalam hal diseminasi informasi, pemanfaatan Facebook sangat membantu. Pengguna perpustakaan tak jarang pula membagi informasi yang diperoleh dari perpustakaan. Hal ini berarti berbagai informasi yang di posting oleh perpustakaan dapat menjangkau pengguna yang lebih luas dan lebih banyak lagi. Mereka akan membagi informasi yang diterima melalui Facebook perpustakaan kepada pengguna lain. Bahkan, alumni dapat tetap memperoleh jangkauan dari perpustakaan. Barangkali mereka tidak dapat berkunjung secara fisik ke perpustakaan, namun tetap mendapat informasi perkembangan perpustakaan kita dan tetap dapat berkomunikasi dengan pustakawannya. Haliniterlihat pada FacebookPerpustakaan Fakultas Geografi, yang menjangkau alumninya, sehingga alumni tetap dapat berkomunikasi, berkomentar tentang perpustakaan, baik koleksi baru maupun kegiatan perpustakaan.

\section{Nunus Wijaya Bukunya bgus2..gmn cra daptnya. \\ Suka - Balas - 21 November 2016 pukul 17:54 \\ 7.7. Perpustakaan Fakultas Geografi Ugm Buku tercetak pak Nunus Wijaya, bisa main ke perpustakaan ..monggo Suka - Balas - 1 1- 6 Desember 2016 pukul 16:03 \\ Nunus Wijaya Yg online g ada ta. Suka - Balas - 6 Desember 2016 pukul 16:04 \\ Perpustakaan Fakultas Geografi Ugm http://link.springer.com/search? query=geography...,}

\section{Search Results - Springer}

This article describes and presents early results from the ESRC. funded Census $2011 \mathrm{Geog}$ project, which aims to develop and evaluate automated procedures to maintain (split, merge or redesign) the 2001 Census outp..

LINK.SPRINGER.COM

Gambar 1. Contoh Komunikasi Perpustakaan Melalui Facebook 
d. Meningkatkan kualitas layanan kepada pengguna

Pada penggunaan Facebook untuk pengembangan layanan sirkulasi, dalam hal ini layanan perpanjangan peminjaman buku perpustakaan oleh Perpustakaan Fakultas ISIPOL, cukup ramai dimanfaatkan oleh mahasiswa. Perpustakaan ISIPOL menyadari bahwa gadget menjadi perangkat yang dominan digunakan oleh penggunanya saat ini, sehingga memberikan fasilitas perpanjangan melalui Facebook. Tentu saja hal ini menunjukkan bahwa pengguna merasa nyaman dan menikmati layanan perpanjangan buku melalui Facebook.

e. Menggambarkan dan meningkatkan perhatian pengguna terhadap perpustakaan

Respons "like" yang diberikan oleh pengguna sebagai salah satu bentuk kepedulian dan perhatian pengguna terhadap perpustakaan. Cukup banyak pengguna yang memberikan komentar yang positif terhadap aktivitas perpustakaan yang diposting di laman Facebook perpustakaan.

\section{Hal-hal yang Harus Diperhatikan dalam Penggunaan Media Sosial}

Penggunaan media sosial untuk pengembangan layanan perpustakaan cukup efektif namun melihat data dokumentasi laman beberapa Facebook perpustakaan di lingkungan Universitas Gadjah Mada sebagai objek kajian ini, maka ada beberapa hal yang perlu mendapat perhatian dari pengelolaan perpustakaan. Pertama, update informasi perlu dilakukan secara rutin. Update informasi secara rutin menunjukkan pemanfaatan yang baik dalam penggunaan Facebook. Hal ini memperlihatkan bahwa Facebook belum dikelola secara baik, untuk mendukung layanan perpustakaan. Secara rutin mengunggah informasi yang penting bagi penggunanya, misalnya koleksi buku baru sebaiknya secara rutin diinformasikan. Dikatakan oleh Collins, ${ }^{11}$ perpustakaan perlu

${ }^{11}$ Gary Collins dan Anabel Quan-Haase, "Social Media and Academic Libraries: Current Trends and Future Challenges”, Proc. Am. Soc. Info. Sci. Tech., Vol. 49, No. 1, 2012, hlm. 1-4. 
secara berkala memberikan informasi kepada pengguna. Penulis yakin bahwa dalam satu tahun kegiatan, pastilah perpustakaan memiliki koleksi, kegiatan atau informasi yang dapat dibagi kepada penggunanya. Kedua respons sesegera mungkin atas tanggapan pengguna, baik berupa pertanyaan maupun tindakan.

\section{Simpulan}

Hasil kajian menunjukkan bahwa Perpustakaan ISIPOL merupakan perpustakaan yang paling sering menggunakan Facebook, diikuti Perpustakaan Fakultas Pertanian dan Perpustakaan Fakultas Geografi. Data dokumentasi pada halaman Facebook perpustakaan menunjukkan penggunaannya untuk berbagai keperluan, yakni untuk mempromosikan koleksi perpustakaan,mempromosikankegiatan ataulayanan perpustakaan, mengunggah foto/gambar kegiatan yang telah dilakukan perpustakaan, mengembangkan jasa layanan sirkulasi terutama untuk perpanjangan peminjaman buku, menginformasikan kegiatan internal perpustakaan, mempromosikan kegiatan dari perpustakaan lain, menginformasikan berbagai hal yang penting bagi pengguna, dan menyapa penggunanya.

Penggunaan Facebook menunjukkan aktivitas dan intensitas yang berbeda-beda. Penggunaan media sosial di perpustakaan memiliki banyak manfaat bagi perpustakaan. Perpustakaan perlu lebih memaksimalkan penggunaan berbagai media sosial untuk dapat berinteraksi lebih intens dengan penggunanya. Belum dimanfaatkan atau belum maksimal dalam pemanfaatannya media sosial untuk layanan perpustakaan, barangkali lebih karena alasan belum adanya sumberdaya manusia (pustakawan) yang memang ditugaskan untuk mengelola Facebook perpustakaan. Namun, hal ini perlu kajian yang lebih mendalam.

Keterbatasan kajian bahasan sederhana mengenai penggunaan Facebook di perpustakaan adalah masih terbatas pada sebagian perpustakaan di lingkungan Universitas Gadjah Mada dan hanya mencermati kegiatan posting yang dilakukan perpustakaan melalui Facebook. Kajian selanjutnya perlu lebih dikembangkan 
dengan mencermati lebih dalam terkait komunikasi perpustakaan melalui pesan yang disampaikan pengguna melalui Facebook yang tidak bersifat publik (melalui icon pesan) dan juga kajian yang lebih mendalam di kemudian hari. 


\section{DAFTAR PUSTAKA}

Burkhardt, Andy, "Sosial Media: A Guide for College and University Libraries", College and Research Libraries News, Vol. 71, No. 1, Januari 2010.

Canty, Nick, "Social Media in Libraries: It's Like, Complicated, Alexandria, 23 (2), 2012, http://search. proquest.com/docview/1356588154?Accountid= 13771 .

Chu, S.K. and H.S. Du, "Social Networking Tools for Academic Libraries", Journal of Librarianship and Information Science, 45 (1), 2013, DOI: 10.1177/0961000611434361.

Collins, Gary dan Anabel Quan-Haase, "Social Media and Academic Libraries: Current Trends and Future Challenges", Proc. Am. Soc. Info. Sci. Tech., Vol. 49, No. 1, 2012.

Itmamudin, "Implementasi Library 3.0 di Perpustakaan IAIN Salatiga: Masalah dan Solusinya”, Libraria: Jurnal Perpustakaan, Vol. 4, No. 1, Juni 2016.

King, D.L., "Landscape of Social Media for Libraries", Library Technology Reports", Vol. 51, No. 1, 2015, https://search. proquest.com/docview/ 1646465094?accountid=13771.

Kurniawan, C.A.U., "Hubungan antara Perkembangan Keterampilan Komunikasi Interpersonal pada Remaja Awal dengan Kecanduan Smartphone", Skripsi, Universitas Gadjah Mada Yogyakarta, 2016.

Larasati, Anitya Putri, "Pemanfaatan Facebook Perpustakaan: Studi Deskriptif Pemanfaatan Jejaring Sosial (Facebook) di Kalangan Anggota Facebook Perpustakaan Kabupaten Sidoarjo", Libri-Net, Vol. 2, No. 2, 2013, http://journal.unair. ac.id/table_of_content_136_volume2_nomor2.html.

Njoroge, G.G. dan P. Kang, "University Libraries and Social Media", Zeitschrift Für Bibliotheks Kultur, 1, September 2013. 